\title{
Ready for the future? Employability skills and competencies in the twenty-first century: The view of international experts
}

\author{
Anna Rakowska ${ }^{\mathrm{a}, *}$ and Susana de Juana-Espinosa ${ }^{\mathrm{b}}$ \\ ${ }^{a}$ Marie Curie Sklodowska University, Lublin, Poland \\ ${ }^{\mathrm{b}}$ Business Organization Department, University of Alicante, Spain
}

Received 14 October 2020

Accepted 6 February 2021

\begin{abstract}
. make current students and employment seekers more employable. as well as the main demand trends for skills and competencies. and in 2019). Each time, they were interviewed to discuss the results. relevant for employability. curriculum in educational institutions.

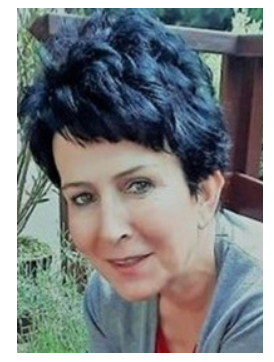

Dr. Anna Rakowska is associate Professor at M. Curie-Skłodowska University in Lublin, Poland. Since 2019 Chair of the Department of Intellectual Capital and Quality. Her research background includes: employee and managerial competencies, management of diverse potential of employees, and HR practices. Vice Dean Vice-Dean for Science and International Cooperation (2008-2011) Faculty of Management at Technical University in Lublin, at later at Faculty of Economics (2012-2015) UMCS.

Dr. Anna Rakowska also served as an editorial board member for
\end{abstract}

BACKGROUND: Today's uncertain economic and social dynamics are leading companies to seek the sort of human talent that will help them to survive and thrive. Training demands are thus arising for specific skills and competencies that would

OBJECTIVE: The aim of this study was to identify the twenty-first century's major employability skills and competencies

METHODS: An international panel of experts (from Spain, Thailand and Poland), from both, academic and professional business backgrounds, were asked to quantitatively project the importance of different generic and specific skills and competencies over the next five years. They were asked to do so twice, once before and once after a four-year interval (in 2016

RESULTS: The most valued employability skills were of a generic nature, in all three countries. Regarding specific skills, those of a social and managerial nature were the most highly valued. Work experience and formal education became less

CONCLUSIONS: The study's results can lead to recommendations on how to design a more employability-oriented

*Corresponding author: Anna Rakowska, Chair of Department of Intellectual Capital and Quality at Faculty of Economics, Maria Curie-Skłodowska University in Lublin, Poland. E-mail: a.rakowska@umcs.lublin.pl. ORCID ID: https://orcid.org/00000002-4990-2297 several international journals, and worked as consultant and trainer for industrial and public companies.

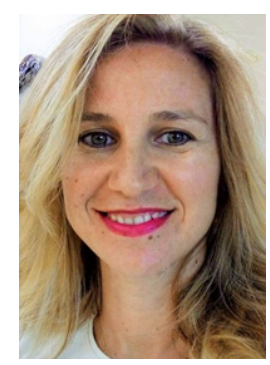

Dr. Susana de Juana-Espinosa holds the position of Assistant Professor for the Department of Business Organization at the University of Alicante (Spain) and is a member of the SIRHO research group. Her main teaching areas are IS management, HRM and ebusiness. Her research topics include e-government, HRM, and MIS. Her research has been published in various conferences and impact journals, and has participated in competitive research projects funded by the European Commission and the Generalitat Valenciana and has also worked as a consultant and trainer for public sector and private organizations. 


\section{Introduction}

Labour markets are defined by the Cambridge Business English Dictionary as "the supply of people in a particular country or area who are able and willing to work, especially in relation to the number of jobs that are available" [1]. Today, all around the world, such labour markets are experiencing dynamic changes which are influencing the demands for new skills and competencies. Several factors are causing these shifts, among which the development of information and communication technologies (ICTs). These technologies are playing a crucial role, generating new forms of cooperation with the environment, creating new jobs, and virtualising work patterns $[2,3]$. At the same time, remote work, or telework, is becoming ever more accessible and popular [4]. Companies are undergoing a fourth industrial revolution, based on the automation of processes and tasks, presenting new opportunities but also challenges to labour market participants $[5,6]$. A new working environment calls for novel strategies to prepare the employability of young generations, which is defined as 'the capability to move self-sufficiently within the labour market to realize potential through sustainable employment' [7, p.2]. Therefore, in order to be employable, people should work on their employability skills. The latter consist, according to [8, p.895] of "knowledge, skills, and competencies that workers need to have in improving their ability to get and keep a job, progress at work, face change, get other jobs if the worker wants to quit from a job or dismissed and enter more easily into the labour market at different periods of their life cycle. The question is whether educational institutions are ready for this change, even though the market is not in short supply of highly skilled employees, but of specific talents. This is especially an issue in countries where the young population is rapidly growing but the education level is very low [9].

Extensive research shows that universities are failing to meet the markets' needs for talent, which has triggered a debate on the value of traditional education methodologies [10] and contents and their capacity to improve graduates' employability [11]. Indeed, while [12] research the current dynamics of skill misalignment between academic push and industry pull, [13] posit that "the logic of education systems should be reversed so that it is the system that conforms to the learner rather than the learner to the system" (p. 317).
Therefore, research is needed on how to transform traditional education models to suit the new situation and finally identify the skills required in the new labour market. This paper presents the results of a longitudinal study conducted simultaneously in three different countries. The objective was to assess the required employability skills and competencies, using a mixed methods methodology. Experts with both, academic and professional business backgrounds were asked to quantify the value of a series of key skills and competences over the five consecutive years to come, once before and once after a four-year interval (i.e. twice, once in 2016 and once in 2019). They were then interviewed to discuss the values they had assigned. Cross-country research is considered critical since the perceived value of higher education in markets varies according to the country [14]. Furthermore, the adaptation strategies followed in different countries are also diverse as they depend on political, economic and social determinants.

This paper thus contributes to the competency gap analysis. Indeed, on the one hand, it evaluates the key factors today and in the future in an international context, and on the other, whether educational institutions have been working on bridging this gap in recent years. The study's primary goal was to identify the most relevant twenty-first century employability skills and competencies. To do so, the primary goal was divided into the following sub-goals:

1. to identify the key employability skills and competencies in three countries (Spain, Poland and Thailand) and analyse potential differences.

2. to determine the main trends in demands for skills and competencies during the study period, and

3. to propose recommendations for a more employability-oriented curriculum.

Specifically, this work contributes to the theoretical debate on the key competences that support employability in the upcoming labour market. It also builds knowledge regarding the Spanish, Polish and Thai labour markets and their prospective skills. This study has practical implications for academics, human resource managers and policy-makers worldwide. Indeed, we set out approaches and methods to develop employability skills, and propose design recommendations for an education strategy supporting the development of employability skills.

The paper is structured as described next. After this introduction, in section 2 below, we present the characteristics of the current labour market and review 
the extensive research on employability issues. In the third section, we explain the research objectives and applied methodology. The results are reported and discussed in the fourth section. To conclude, we advance a series of recommendations to achieve a more market-oriented curriculum based on the experts' opinions and that should foster employability skills.

\section{Labour market trends and employability skills and competencies}

\subsection{Employability skills and competencies: Definition and challenges}

Employability is defined as a key individual resource that can be reinforced to help people face a constantly changing labour market, characterised by unpredictability and insecurity [15]. Employability can also be related to a number of factors, namely: personal resources, employability orientation, occupational expertise, optimisation of opportunities, sustainability of work, qualifications, and futureoriented perspectives meta-competences [16].

Specifically, the concept of employability, understood as a competency, is relevant to higher education institutions (HEIs) who can develop it in order to prepare young people to be successful in the new labour market [16], in the sense that "Competences can be understood as wide-ranging combinations of know-how - composites of knowledge, skills and attitudes possessed by an individual. Competences illustrate the person's proficiency, capacity and ability to perform in professional tasks' [17, pp. 30-31]. Today however, the issue of graduates' employability transcends HEIs' tradition of providing useful and matching knowledge, skills and attitudes; discussions are necessary, especially in view of the effects of digitalisation on the labour market [18]. Employability gaps can even be observed in developed countries with well-educated populations, especially among young citizens [19]. Naudé [20] suggests that the Czech Republic, Lithuania, Hungary, and Slovenia are the only Central and Eastern European countries to be somewhat ready to face these challenges. Others, such as Slovakia, Romania, and Poland are the least prepared. Some countries have undertaken appropriate actions [21, 22], as in the case of Singapore's "Smart Nation" plan. This latter country has adjusted its education system by introducing innovative learning methodologies in schools and helping students to develop generic employability skills [23].
Therefore, it seems that, in order to increase employability expectations, it is necessary to anticipate the skills demanded across different jobs and work settings, rather than focus on future jobs. That is precisely the goal that is addressed in the following three reports: a) Future Work Skills 2020 [24]; b) The future of work: jobs and skills in 2030 [25] and c) World Bank Report [26]. These three reports identify several key drivers and factors of change in the labour market. The reports share similarly acknowledge technological change, social change, globalisation, and the intertwining of different spheres of our lives as the most influential factors. Additionally, the importance of environmental, social and political problems is emphasized in [24], while economic development differences are more patently stressed in [25]. Other critical factors mentioned for the European labour market include: the increase of female labour participation; the inflow of non-EU labour; population movements between EU countries; and the growing divide of the EU labour market [26].

In this context, EU education systems are being generally criticised for not providing equal opportunities for developing skills [26]. Similar trends were found in many Asian countries [27], such as Thailand, where multiple challenges are being faced with the establishing of vibrant, innovative education systems [28]. Therefore, new strategies are required to help young workers all other the world build their employability skills: if future employees are to be productive and competitive, they must possess the appropriate skills and competencies; the latter is the shared responsibility of practitioners, HEIs, researchers, policy-makers and students [29].

\subsection{State of the art}

Several inventories of employability competencies can be found in the literature. One of them is the list given in [24] of 10 generic key competencies for the future labour market:

1 Sense-making. Ability to determine the deeper meaning or significance of what is being expressed; this activity enables transforming the world's ongoing complexity into comprehended situations.

2 Social intelligence. Ability to connect to others in a deep and direct way, to sense and stimulate reactions and desired interactions. Ability to swiftly assess the emotions of others, adapt to their register, vocabulary and style. 
3 Novel and adaptive thinking. Proficiency at thinking up solutions and answers beyond rule-based or routine responses. Situational adaptability to address unique or unexpected emerging circumstances.

4 Cross-cultural competency. Ability to operate in different cultural settings. Linguistic skills, adaptability to changing circumstances, ability to sense and respond to new cultural contexts.

5 Computational thinking. Ability to translate vast amounts of data into abstract concepts, models, and to understand data-based reasoning.

6 New media literacy. Ability to critically assess as well as generate content that uses new media forms, and to leverage these media to communicate in a persuasive way. Fluency in new forms, ability to read contexts "critically". Ability to create and present own visual information, presentations.

7 Transdisciplinarity. Ability to understand concepts across multiple disciplines. Specialists who can speak languages of multiple disciplines, e.g. biologists with an understanding of mathematics, or mathematicians with an understanding of biology.

8 Design mindset. Ability to represent and develop tasks and work processes for desired outcomes. Recognising and adapting various kinds of thinking required by different tasks, and adjusting to work environments. This is not a problem-focused approach but rather a solutionfocused and action-oriented approach.

9 Cognitive load management. Ability to discriminate and filter important information, and to understand how to maximise cognitive functioning by using a variety of tools and techniques. Ability to turn the massive influx of data into an advantage. Tackling the problem of cognitive overload.

10 Virtual collaboration. Ability to work productively, drive engagement and demonstrate presence as a member of a virtual team. Motivating a dispersed group, e.g. use of techniques borrowed from gaming to involve large virtual communities.

In another line of thought, [30] underline that modern competencies refer to gaining knowledge needed for understanding and solving real-world problems. The latter especially refer to:

- Learning and innovation skills, which include creativity and innovation, critical thinking and problem solving, as well as communication and collaboration.

- Digital literacy skills, which include information literacy, media literacy, and ICT literacy.

- Career and life skills, which include flexibility and adaptability, initiative and self-direction, social and cross-cultural skills, productivity and accountability, leadership and responsibility.

In addition, and according to [31], three groups of skills will be the most needed in the labour market by 2030 (p. 9):

- Technical and digital competencies (understanding of advanced digital technologies, the ability to develop and adapt them): by 2030, workers in Europe and the US are forecast to spend over $40 \%$ of their time on activities that will require these competences; only a few employees, however, will actually possess them.

- Social competencies: by 2030, demand for social competences would increase by $22 \%$ (in particular, companies would seek employees with entrepreneurship- related competences and the ability to take initiatives);

- Higher cognitive competencies: these refer to a range of sophisticated thinking skills, including creativity and complex information processing and interpretation. The demand for these skills is expected to increase by $8 \%$ by 2030 .

These competencies have many common features with the proposed competences listed by [25]. Moreover, in an increasingly data-driven economy, the demand for "soft" social skills, such as teamwork and communication will grow [12, 32, 33].

To summarise, different labour markets are undergoing changes due to the same, shared global factors. Nevertheless, the impact of the various factors varies according to the countries' levels of preparedness to develop employability skills $[19,28]$. In addition, the competences underlying this employability are of a generic nature [24], although demands for more specific skills, such as social and ICT-related skills are also expected [30,12].

\subsection{Key labour market and workforce characteristics in Spain, Poland and Thailand}

Spain, Poland and Thailand are all OECD members. Thailand is the most recent, having joined in 2018. The differences between the Spanish, Polish 
and Thai labour markets are, however, noticeable, especially regarding unemployment rates and the employment structure.

Starting with unemployment rates, Thailand's is extremely low. i.e. below $1 \%$ since 2011 [34]. The reasons are a low birth rate, lack of social insurance and an extensive informal sector: 64\% of the labour force consists of street vendors, motorbike taxis, and other self-employed citizens. Spain's labour market trends differ from that of most EU countries, which could be explained by deep-seated domestic problems [35]. Currently, Spain and Greece have the EU's highest unemployment rates while Poland presents one of the lowest rates [36]. In 2019, the country accounted for a record-low unemployment rate of 3 , $27 \%$ [37].

Regarding the structure of employment by sector in 2020, most of Thailand's labour force works in the service sector (46\%), and a large number is employed in agriculture. Spain's structure is dominated by the service sector $(75.83 \%)$, followed by industry (20.18\%), and only $4 \%$ of the workforce are employed in agriculture [38]. In Poland, the service sector accounts for 58,8\% of employment, industry for $31,9 \%$, and agriculture for $9,24 \%$ [39].

With respect to the number of top universities in all three countries, the highest ranking is held by Spain (11), followed by Thailand (37) and Poland (43) [40]. In 2018, the number of university graduates aged between 25-34 years in Spain and Poland were similar: around 44\% [41]. In Thailand, the labour market consists mostly of a low-skilled workforce and suffers from a huge shortage of skilled labour [42]. However, in 2019, 52\% of Thai workers with bachelor degrees and other graduates held jobs that were unrelated to their studies [43]. Spain and Poland suffer from an insufficient use of employee skills in the workplace, especially in high performance workplace systems [44-46]. This means that in all three cases, HEIs have not been keeping up with the pace of quality changes, resulting in a mismatch between skill supply and labour market demands.

In conclusion, all three countries have the common problem of determining and offering the skillsets required by their different labour markets and employment demands in the new economy, to bridge the fracture between personal competency development and company talent management policies. However, the nature of the fracture is different in each country, and therefore the question is if these differences are also present in the skills and competencies considered most valuable now and in the near future.

\section{Methods}

The present study was carried out using a mixed method approach [47]. Experts from all three countries performed their assessments twice (once in 2016 and once in 2019) and over three rounds, covering the 2016-2025 period. A mixed research methodology is well-adapted to the field of education research [48], especially in multifaceted studies. The present work was an international collaboration between three universities in different countries: University of Alicante in Spain, Kasetsart University in Bangkok, Thailand, and Marie Curie-Sklodowska University in Lublin, Poland. Thailand was chosen as representative of Asian societies, while Poland and Spain exemplified different cultures within the EU.

The consulted experts reflected a mix of fields of experience from the academic and professional business worlds. Identifying the experts was a key part of the methodology, since a team of experts presenting a range of knowledge and experience would be better at identifying future events than one specialist alone, provided the communication process is welldesigned and focused discussions take place.

As shown in Table 1, the experts were consulted three times to obtain the required data, based on a quantitative-qualitative-quantitative sequence. The quantitative data in both rounds was gathered from a Likert survey (ranging from 1-not important- to 5-extremely important), listing 31 skills and competences needed in the twenty-first century (see Annex). The latter had been selected after performing a critical literature review.

These 31 competences and skills were grouped into two categories: generic and specific. The first category corresponds to the list of the 10 skills described by [24], which had been previously used by other researchers [49-51]. The ensuing 21 specific competences were divided into five clusters:

- Self-management skills (6): conscious selfdevelopment, ability to self-motivate one's self to work long hours personal stress management, learning skills, flexibility, and tolerance of uncertainty [52, 53].

- Social skills (5): face to face communication, building trust and good relations, social entrepreneurship, e-cooperation/communication, project management $[54,55]$.

- IT skills (3): high technology entrepreneurship, collaborative innovation using web tools, big data and cloud management proficiency. Skills 
Table 1

Research methodology

\begin{tabular}{|c|c|c|c|}
\hline Country & Round & Methodology & No. of participants \\
\hline \multirow[t]{3}{*}{ Poland } & First-2015 (data 2015-2020) & Quantitative survey & 9 (5 academics, 4 business) \\
\hline & Second -2016 (data 2015-2020) & Face- to- face debates + survey & \\
\hline & Third-2019 (data 2019-2024) & Quantitative survey & \\
\hline \multirow[t]{3}{*}{ Spain } & First-2015 (data 2015-2020) & Quantitative survey & 10 ( 5 academics, 5 business) \\
\hline & Second -2016 (data 2015-2020) & Face- to- face debates + survey & \\
\hline & Third-2019 (data 2019-2024) & Quantitative survey & 9 (5 academics, 4 business) \\
\hline \multirow[t]{3}{*}{ Thailand } & First-2015 (data 2015-2020) & Quantitative survey & 10 ( 5 academics, 5 business) \\
\hline & Second -2016 (data 2015-2020) & Face- to- face debates + survey & \\
\hline & Third-2019 (data 2019-2024) & Quantitative survey & 9 (5 academics, 4 business) \\
\hline
\end{tabular}

and competencies from this group are on markets' top list of requisites $[54,56]$

- Diversity management skills (5): skills to aptly cooperate with people from different cultures, religion, age group or sex, or simply ability to work in diversified teams, which is particularly necessary in a global labour market $[57,59]$.

- Background skills (2) - formal education and work experience $[59,60]$.

The first stage of the study took place between December 2015 and January 2016. The experts were sent the survey by email, in English for Spain and Thailand, in Polish for Poland, and were asked to assess the importance of each of the 31 competencies at two different moments in time: "now" (referring to 2015), and "in five years' time" (referring to 2020), using the template in Annex 1. Generic and specific competencies were the only ones to be explicitly separated, in order to prevent biases. Once the experts had sent back their quantitative responses, the results were analysed per country as well as jointly. Three country reports with their respective summary of values were then forwarded to each group of experts.

In 2016, face to face meetings were arranged with the experts in Spain (February), Thailand (March), and Poland (May). In this second stage, the research team presented the results to the experts who were given the chance to discuss and justify their opinions among themselves and with the research team. After the presentation and discussions had ended, the experts were asked to re-evaluate their opinion on the importance of the competencies using the same questionnaire as in the previous stage. The contents of the qualitative discussions were collected, as well as the renewed perceptions following the debate. The experts were informed that the study would be continued in 2019.
Finally, in 2019, the experts were asked to repeat the process. The updated 2016 result summary reports were e-mailed to the same experts, who were asked once again to fill out the questionnaire. The perspective, however, of "now" was 2019 and "in five years' time" referred to 2024. This latter quantitative data was used to prepare a new 2019 summary report.

\section{Results}

The results of this study consisted of the most valued competencies to achieve employability in three countries at two different moments (in 2015 and in 2019), based on expert views, as described in Table 1. The five generic and five specific competencies with the highest mean values listed per country and year are shown in Table 3 (Spain), Table 4 (Thailand) and Table 5 (Poland). The competencies that were among the top five on at least three occasions in each country are indicated in bold letters. The discussion comments stem from the analysis of the quantitative data and the discussions that took place in each country between the experts. The values for $2015 / 2020$ correspond to the revised perceptions after the second round of data collection.

\subsection{Top competences in 2015 and 2019}

The first notable finding is that based on the total values given to each competency in 2015 and 2019, all 10 generic competences were given higher assessments in the final phase of the research; such increases were statistically significant with $p$-values smaller than 0,05 except for the competencies: "Social intelligence" and "Computational thinking" (means and $t$-test results are shown in Table 2). We can infer that 
Table 2

Skill importance. Difference of means ( $t$-test) between 2016 and 2019

\begin{tabular}{|c|c|c|c|c|c|c|c|c|c|c|}
\hline \multirow{2}{*}{$\begin{array}{l}\text { Skill } \\
\text { No. }\end{array}$} & & & & \multirow[t]{2}{*}{$\mathrm{T}$} & \multirow[t]{2}{*}{ dof } & \multirow{2}{*}{$\begin{array}{l}\text { Bil. } \\
\text { Sig. }\end{array}$} & \multirow{2}{*}{$\begin{array}{c}\text { Diff. of } \\
\text { means }\end{array}$} & \multirow[t]{2}{*}{ SD } & \multicolumn{2}{|c|}{ IC (95\%) } \\
\hline & & & & & & & & & Lower & Higher \\
\hline \multirow[t]{2}{*}{1} & Equal variances & 1,195 & 0,279 & 2,423 & 54 & 0,019 & 0,46616 & 0,19238 & 0,08046 & 0,85185 \\
\hline & Non- equal variances & & & 2,438 & 53,550 & 0,018 & 0,46616 & 0,19124 & 0,08267 & 0,84964 \\
\hline \multirow[t]{2}{*}{2} & Equal variances & 0,002 & 0,967 & 0,433 & 54 & 0,667 & 0,07663 & 0,17692 & $-0,2781$ & 0,43132 \\
\hline & Non- equal variances & & & 0,434 & 53,992 & 0,666 & 0,07663 & 0,17653 & $-0,2773$ & 0,43055 \\
\hline \multirow[t]{2}{*}{3} & Equal variances & 0,190 & 0,665 & 2,165 & 54 & 0,035 & 0,36526 & 0,16871 & 0,02701 & 0,70351 \\
\hline & Non- equal variances & & & 2,185 & 52,211 & 0,033 & 0,36526 & 0,16715 & 0,02988 & 0,70065 \\
\hline \multirow[t]{2}{*}{4} & Equal variances & 0,395 & 0,533 & 3,024 & 54 & 0,004 & 0,64368 & 0,21285 & 0,21694 & 1,07042 \\
\hline & Non- equal variances & & & 3,040 & 53,712 & 0,004 & 0,64368 & 0,21173 & 0,21914 & 1,06822 \\
\hline \multirow[t]{2}{*}{5} & Equal variances & 4,834 & 0,032 & 1,240 & 54 & 0,220 & 0,23116 & 0,18640 & $-0,1426$ & 0,60488 \\
\hline & Non- equal variances & & & 1,251 & 52,347 & 0,216 & 0,23116 & 0,18473 & $-0,1395$ & 0,60179 \\
\hline \multirow[t]{2}{*}{6} & Equal variances & 13,53 & 0,001 & 4,125 & 54 & 0,000 & 0,74202 & 0,17987 & 0,38141 & 1,10263 \\
\hline & Non- equal variances & & & 4,209 & 43,613 & 0,000 & 0,74202 & 0,17630 & 0,38661 & 1,09742 \\
\hline \multirow[t]{2}{*}{7} & Equal variances & 6,507 & 0,014 & 3,721 & 54 & 0,000 & 0,76884 & 0,20662 & 0,35458 & 1,18309 \\
\hline & Non- equal variances & & & 3,773 & 49,053 & 0,000 & 0,76884 & 0,20375 & 0,35940 & 1,17828 \\
\hline \multirow[t]{2}{*}{8} & Equal variances & 0,887 & 0,350 & 3,020 & 54 & 0,004 & 0,66539 & 0,22032 & 0,22368 & 1,10710 \\
\hline & Non- equal variances & & & 3,034 & 53,862 & 0,004 & 0,66539 & 0,21933 & 0,22563 & 1,10515 \\
\hline \multirow[t]{2}{*}{9} & Equal variances & 0,992 & 0,324 & 2,880 & 54 & 0,006 & 0,60920 & 0,21156 & 0,18505 & 1,03334 \\
\hline & Non- equal variances & & & 2,906 & 52,215 & 0,005 & 0,60920 & 0,20960 & 0,18864 & 1,02975 \\
\hline \multirow[t]{2}{*}{10} & Equal variances & 0,134 & 0,716 & 4,480 & 54 & 0,000 & 0,76884 & 0,17161 & 0,42479 & 1,11289 \\
\hline & Non- equal variances & & & 4,470 & 53,024 & 0,000 & 0,76884 & 0,17200 & 0,42385 & 1,11382 \\
\hline \multirow[t]{2}{*}{11} & Equal variances & 0,255 & 0,615 & 3,152 & 54 & 0,003 & 0,60153 & 0,19083 & 0,21895 & 0,98412 \\
\hline & Non- equal variances & & & 3,157 & 53,948 & 0,003 & 0,60153 & 0,19054 & 0,21952 & 0,98354 \\
\hline \multirow[t]{2}{*}{12} & Equal variances & 2,397 & 0,127 & 0,281 & 54 & 0,780 & 0,06769 & 0,24079 & $-0,4151$ & 0,55043 \\
\hline & Non- equal variances & & & 0,284 & 51,438 & 0,777 & 0,06769 & 0,23823 & $-0,4105$ & 0,54586 \\
\hline \multirow[t]{2}{*}{13} & Equal variances & 7,898 & 0,007 & 1,559 & 54 & 0,125 & 0,31801 & 0,20401 & $-0,091$ & 0,72703 \\
\hline & Non- equal variances & & & 1,583 & 48,058 & 0,120 & 0,31801 & 0,20093 & $-0,086$ & 0,72200 \\
\hline 14 & Equal variances & 0,075 & 0,785 & 2,467 & 54 & 0,017 & 0,45211 & 0,18326 & 0,08470 & 0,81951 \\
\hline & Non- equal variances & & & 2,493 & 51,665 & 0,016 & 0,45211 & 0,18138 & 0,08808 & 0,81613 \\
\hline 15 & Equal variances & 1,234 & 0,272 & 1,287 & 54 & 0,204 & 0,26437 & 0,20542 & $-0,1475$ & 0,67622 \\
\hline & Non- equal variances & & & 1,297 & 52,957 & 0,200 & 0,26437 & 0,20385 & $-0,1445$ & 0,67325 \\
\hline 16 & Equal variances & 1,067 & 0,306 & 3,725 & 54 & 0,000 & 0,65262 & 0,17518 & 0,30141 & 1,00383 \\
\hline & Non- equal variances & & & 3,728 & 53,830 & 0,000 & 0,65262 & 0,17507 & 0,30160 & 1,00364 \\
\hline 17 & Equal variances & 2,502 & 0,120 & 0,583 & 54 & 0,562 & 0,11750 & 0,20153 & $-0,2865$ & 0,52153 \\
\hline & Non- equal variances & & & 0,587 & 53,035 & 0,559 & 0,11750 & 0,20002 & $-0,2837$ & 0,51868 \\
\hline 18 & Equal variances & 0,498 & 0,483 & 0,630 & 54 & 0,531 & 0,12899 & 0,20460 & $-0,2812$ & 0,53919 \\
\hline & Non- equal variances & & & 0,635 & 53,298 & 0,528 & 0,12899 & 0,20322 & $-0,2786$ & 0,53654 \\
\hline 19 & Equal variances & 0,793 & 0,377 & 7,151 & 54 & 0,000 & 1,20051 & 0,16787 & 0,86395 & 1,53707 \\
\hline & Non- equal variances & & & 7,244 & 49,894 & 0,000 & 1,20051 & 0,16571 & 0,86765 & 1,53338 \\
\hline 20 & Equal variances & 0,001 & 0,977 & 1,785 & 54 & 0,080 & 0,40358 & 0,22605 & $-0,0496$ & 0,85677 \\
\hline & Non- equal variances & & & 1,783 & 53,285 & 0,080 & 0,40358 & 0,22640 & $-0,0505$ & 0,85762 \\
\hline 21 & Equal variances & 1,022 & 0,316 & 0,701 & 54 & 0,486 & 0,17114 & 0,24399 & $-0,318$ & 0,66030 \\
\hline & Non- equal variances & & & 0,698 & 51,731 & 0,488 & 0,17114 & 0,24521 & $-0,321$ & 0,66325 \\
\hline 22 & Equal variances & 7,145 & 0,010 & 0,497 & 54 & 0,621 & 0,12005 & 0,24144 & $-0,364$ & 0,60411 \\
\hline & Non- equal variances & & & 0,504 & 49,508 & 0,617 & 0,12005 & 0,23822 & $-0,3585$ & 0,59864 \\
\hline 23 & Equal variances & 1,084 & 0,303 & 2,004 & 54 & 0,050 & 0,48659 & 0,24285 & $-0,0003$ & 0,97347 \\
\hline & Non- equal variances & & & 2,000 & 53,133 & 0,051 & 0,48659 & 0,24334 & $-0,0015$ & 0,97463 \\
\hline
\end{tabular}


Table 2

Continued

\begin{tabular}{|c|c|c|c|c|c|c|c|c|c|c|}
\hline \multirow{2}{*}{$\begin{array}{l}\text { Skill } \\
\text { No. }\end{array}$} & & & & \multirow[t]{2}{*}{$\mathrm{T}$} & \multirow[t]{2}{*}{ dof } & \multirow{2}{*}{$\begin{array}{l}\text { Bil. } \\
\text { Sig. }\end{array}$} & \multirow{2}{*}{$\begin{array}{l}\text { Diff. of } \\
\text { means }\end{array}$} & \multirow[t]{2}{*}{ SD } & \multicolumn{2}{|c|}{ IC (95\%) } \\
\hline & & & & & & & & & Lower & Higher \\
\hline \multirow[t]{2}{*}{24} & Equal variances & 16,12 & 0,000 & 1,767 & 54 & 0,083 & 0,34738 & 0,19655 & $-0,0467$ & 0,74145 \\
\hline & Non- equal variances & & & 1,799 & 45,542 & 0,079 & 0,34738 & 0,19305 & $-0,0413$ & 0,73607 \\
\hline \multirow[t]{2}{*}{25} & Equal variances & 2,372 & 0,129 & 3,114 & 54 & 0,003 & 0,63346 & 0,20343 & 0,22561 & 1,04132 \\
\hline & Non- equal variances & & & 3,136 & 53,231 & 0,003 & 0,63346 & 0,20202 & 0,22831 & 1,03861 \\
\hline \multirow[t]{2}{*}{26} & Equal variances & 0,430 & 0,515 & 4,106 & 54 & 0,000 & 0,87484 & 0,21308 & 0,44764 & 1,30204 \\
\hline & Non- equal variances & & & 4,127 & 53,732 & 0,000 & 0,87484 & 0,21198 & 0,44981 & 1,29988 \\
\hline \multirow[t]{2}{*}{27} & Equal variances & 2,198 & 0,144 & 3,434 & 54 & 0,001 & 0,75096 & 0,21871 & 0,31248 & 1,18944 \\
\hline & Non- equal variances & & & 3,481 & 49,262 & 0,001 & 0,75096 & 0,21572 & 0,31751 & 1,18440 \\
\hline \multirow[t]{2}{*}{28} & Equal variances & 0,082 & 0,776 & 4,173 & 54 & 0,000 & 0,84036 & 0,20140 & 0,43657 & 1,24414 \\
\hline & Non- equal variances & & & 4,179 & 53,955 & 0,000 & 0,84036 & 0,20108 & 0,43721 & 1,24350 \\
\hline \multirow[t]{2}{*}{29} & Equal variances & 1,603 & 0,211 & 4,028 & 54 & 0,000 & 0,79821 & 0,19815 & 0,40095 & 1,19548 \\
\hline & Non- equal variances & & & 4,053 & 53,540 & 0,000 & 0,79821 & 0,19697 & 0,40324 & 1,19318 \\
\hline \multirow[t]{2}{*}{30} & Equal variances & 0,089 & 0,767 & $-2,57$ & 54 & 0,013 & $-0,5581$ & 0,21679 & $-0,9927$ & $-0,1235$ \\
\hline & Non- equal variances & & & $-2,59$ & 53,710 & 0,012 & $-0,5581$ & 0,21564 & $-0,9905$ & $-0,1257$ \\
\hline \multirow[t]{2}{*}{31} & Equal variances & 2,121 & 0,151 & 0,725 & 54 & 0,472 & 0,15709 & 0,21682 & $-0,2776$ & 0,59178 \\
\hline & Non- equal variances & & & 0,731 & 52,283 & 0,468 & 0,15709 & 0,21484 & $-0,274$ & 0,58814 \\
\hline
\end{tabular}

Table 3

Spain's 10 most valued skills for current and prospect employability per country and year

\begin{tabular}{llllc}
\hline Spain & Actual 2015 & Actual 2019 & Exp. 2020 & Exp. 2024 \\
\hline Generic & Novel \& adaptive thinking & Novel \& adaptive thinking & Novel \& adaptive thinking & Novel \& adaptive thinking \\
& $\mathbf{( 4 . 2 )}$ & $\mathbf{( 4 . 4 )}$ & $\mathbf{( 4 . 9 )}$ & $\mathbf{( 4 . 9 )}$ \\
& Social intelligence (4.3) & Social intelligence (4.3) & Social intelligence (4.9) & Social intelligence (4.7) \\
& New media literacy (3.6) & New media literacy (4.2) & Cognitive load management & Cognitive load management \\
& & & $(4.8)$ & $(4.8)$ \\
& Cross cultural competency & Cross cultural competency & Cross cultural competency & Cross cultural competency \\
& $\mathbf{( 4 . 0 )}$ & $\mathbf{( 4 . 4 )}$ & $\mathbf{( 4 . 8 )}$ & (4.6) \\
& Sense-making (4.1) & Transdisciplinarity (4.2) & Virtual collaboration (4.8) & Computational thinking (4.6) \\
Specific & Building trust and good & Building trust and good & Ability to work in diversified & Building trust and good \\
& relations (4.5) & relations (4.7) & teams (4.9) & relations (4.6) \\
& Formal education (4.4) & Ability to work in diversified & E-cooperation (4.7) & E-cooperation (4.7) \\
& Flexibility (4.3) & teams (4.3) & & Flexibility (4.6) \\
& Learning skills (4.2) & Learning skills (4.6) & Learning skills (4.8) & Learning skills (4.7) \\
& Project management (3.9) & Conscious self-development & Cooperation with people & Social entrepreneurship (4.8) \\
& $(4.3)$ & representing different &
\end{tabular}

employability measures should focus on the acquisition of the generic skills listed.

As for the specific competencies, they were also perceived as more important in 2019 in all cases except "Formal Education" which was significantly less valued in the second round for the generic skills and, incidentally, in all three countries separately, although not significantly in these latter instances ( $p$-value $>0,05$, see Table 2 ).

Some competencies were common to all three countries and research moments in time, specifically, the "Novel and adaptive thinking" generic skill 
Table 4

Thailand's 10 most valued skills for current and prospect employability per country and year

\begin{tabular}{|c|c|c|c|c|}
\hline Thailand & Actual 2015 & Actual 2019 & Exp. 2020 & Exp. 2024 \\
\hline \multirow[t]{5}{*}{ Generic } & $\begin{array}{l}\text { Novel \& adaptive thinking } \\
\quad(3.8)\end{array}$ & $\begin{array}{l}\text { Novel \& adaptive thinking } \\
(4.4)\end{array}$ & $\begin{array}{l}\text { Novel \& adaptive thinking } \\
\text { (4.7) }\end{array}$ & $\begin{array}{l}\text { Novel \& adaptive thinking } \\
\text { (4.7) }\end{array}$ \\
\hline & Design mindset (3.9) & Virtual collaboration (4.4) & Design mindset (4.7) & Design mindset (4.7) \\
\hline & New media literacy (3.9) & Sense-making (4.9) & New media literacy (4.8) & Social intelligence (4.7) \\
\hline & Social intelligence (4.0) & $\begin{array}{l}\text { Cross cultural competency } \\
\text { (4.4) }\end{array}$ & $\begin{array}{l}\text { Cross cultural competency } \\
\text { (4.8) }\end{array}$ & $\begin{array}{l}\text { Cross cultural competency } \\
\text { (4.8) }\end{array}$ \\
\hline & Computational thinking (4.2) & Transdisciplinarity (4.3) & Computational thinking (4.7) & Computational thinking (4.7) \\
\hline \multirow[t]{5}{*}{ Specific } & $\begin{array}{l}\text { Building trust and good } \\
\text { relations (4.1) }\end{array}$ & $\begin{array}{l}\text { Big data and cloud } \\
\text { management }(4.4)\end{array}$ & $\begin{array}{l}\text { Big data and cloud } \\
\text { management }(4.7)\end{array}$ & $\begin{array}{l}\text { Big data and cloud } \\
\text { management (5) }\end{array}$ \\
\hline & Learning skills (4.3) & Learning skills (4.7) & Learning skills (4.8) & Learning skills (4.9) \\
\hline & Flexibility (4.3) & Social entrepreneurship (4.3) & Flexibility (4.8) & Flexibility (4.9) \\
\hline & $\begin{array}{l}\text { Face-to-face communication } \\
\text { (4.0) }\end{array}$ & E-cooperation (4.3) & $\begin{array}{l}\text { Virtual collaborative } \\
\text { innovation (4.7) }\end{array}$ & E-cooperation (5) \\
\hline & $\begin{array}{l}\text { Cooperation with people } \\
\text { representing different cultures } \\
\text { (3.9) }\end{array}$ & $\begin{array}{l}\text { Conscious self-development } \\
\text { (4.2) }\end{array}$ & Work experience (4.8) & $\begin{array}{l}\text { Conscious self-development } \\
\text { (4.8) }\end{array}$ \\
\hline
\end{tabular}

Table 5

Poland's 10 most valued skills for current and prospect employability per country and year

\begin{tabular}{llllc}
\hline Poland & Actual 2015 & Actual 2019 & Exp. 2020 & Exp. 2024 \\
\hline Generic & Novel \& adaptive thinking & Novel \& adaptive thinking & Novel \& adaptive thinking & Novel \& adaptive thinking \\
& $\mathbf{3 . 9}$ & $\mathbf{( 4 . 3 )}$ & $\mathbf{( 4 . 8 )}$ & $\mathbf{( 4 . 8 )}$ \\
& Cognitive load & Cognitive load & Cognitive load & Cognitive load \\
& management (3.7) & management (4.2) & management (4.5) & management (4.8) \\
& Sense-making (3.5) & New media literacy (4.1) & New media literacy (4.6) & Transdisciplinarity (4.4) \\
& Transdisciplinarity (3.3) & Cross cultural competency & Cross cultural competency & Cross cultural competency \\
& & $(\mathbf{4 . 1})$ & $\mathbf{( 4 . 5 )}$ & $\mathbf{( 4 . 4 )}$ \\
& Social intelligence (3.5) & Social intelligence (4.0) & Virtual collaboration (4.6) & Virtual collaboration (4.8) \\
Specific & Building trust and good & Flexibility (4.3) & Building trust and good & Flexibility (4.7) \\
& relations (4.1) & relations (4.8) & E-cooperation (4.9) \\
& Formal education (3.9) & E-cooperation (4.2) & E-cooperation (4.8) & Web-based collaborative \\
& Work experience (3.7) & Project management (4.3) & Web-based collaborative & innovation (4.6) \\
& & innovation (4.8) & Ability to work in diversified \\
& Learning skills (3.9) & Learning skills (4.2) & Learning skills (4.7) & teams (4.7)
\end{tabular}

and the self-management skills "Learning skills" and "Conscious self-development". Each presented higher values in all cases. In 2019, another common generic skill, "Cross-cultural competency", was revealed: it had only been considered in 2015 among the top skills by the Spanish experts. Therefore, some competencies can be regarded as more global than others, especially those related to self-management, and differences between countries seem to diminish over time. Figure 1 illustrates these common values, and clearly shows that Polish experts consistently valued these skills less than the others.

In 2015, in Spain, the most valued skills were a mix of generic and specific ones, whereas in 2019, the top five were only of the generic kind, as shown in Table 3. It is equally worth noting that the seven 


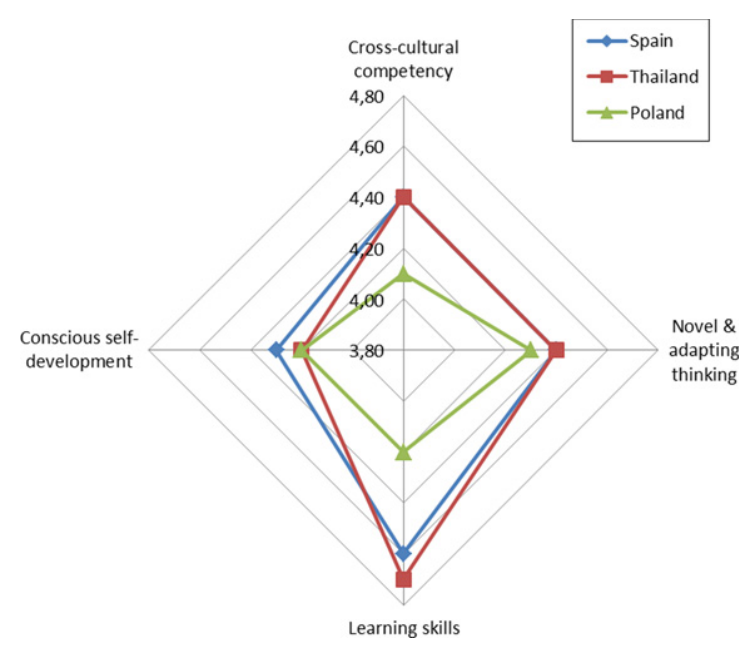

Fig. 1. Common most valued competences in 2015 and 2019(2019 values).

skills deemed most valuable in 2015 were the same as in 2019, all reaching higher values in that year. We could thus interpret that these skills are gaining in importance in the Spanish labour market. A striking result is the drop in value of the generic "Sensemaking" skill (which had a lower score in 2019 than in 2015) and the specific competences "Formal education", and "Project management" (which, nonetheless, were more valued in 2019), while more versatile skills such as "Transdisciplinarity", "Conscious self-development" or "Ability to work in diversified teams" indicate a need for more polyvalent employees.

On the other side of the spectrum, Thai experts made rather large adjustments to their priorities between 2015 and 2019 (see Table 4). Labour market changes and social and political instability may underlie this evolution. In this case, certain social-related skills were highlighted in 2019 (i.e. "Ecooperation" or "Social entrepreneurship") as well as IT-related skills (such as "Big data and cloud management proficiency"), together with other generic skills, for example "Virtual collaboration".

Lastly, as can be observed in Table 5, Polish experts kept half of the 2015 most valued competencies (specifically, generic and social skills such as "Novel \& adaptive thinking", "Social intelligence", "Cognitive load management" "Learning skills" and "Conscious self-development") in the main 2019 list. At the same time, they gave notably higher values to these labour market skillsets in 2019 than in 2015. Unlike Spain and Thailand, the most valued competencies were specific ones in both surveys, though they agreed that "Formal education" was less valuable in the 2019 ranking than in 2015, along with "Work experience", "Building trust and good relations", "Sense-making" and "Transdisciplinarity". The latter two were granted more importance in both Thailand and Spain in 2019, once more emphasizing the dissimilarities between the studied countries and their labour contexts.

\subsection{Highest valued prospective competencies in 2020 and 2024}

Results were also obtained based on what was deemed to be important for employability in 2020 according to the experts back in 2015 , and what would be important in 2024 according to the experts in 2019. The generic analysis of the evolution of the expectations between 2020 (as of 2015) and 2024 (as of 2019) produced an interesting picture. All generic competences and two thirds of the specific skills were collectively assessed with lower values for 2024, even if their position in the ranking had not substantially changed. Only IT-related skills were consistently perceived as more relevant in 2024's market than in that of 2020, enhancing their key role for future employment.

Four commonly highly perceived skills in all three countries in 2024 and their prospective values in 2020 are illustrated in Fig. 2: two generic skills ("Novel and adaptive thinking" and "Cross-cultural competency") and two specific skills ("Flexibility" and "E-cooperation"). No common pattern was thus visible in how experts projected the changes.

Tables 3, 4 and 5 also show that the top prospective skills in 2020 and 2024 were almost the same in all three countries, with some particularities. In Spain (Table 3), four of the five generic skills were the same in both estimates, with either similar or slightly lower perceived values. One sole exception was "Virtual collaboration", which was replaced by "Computational thinking". Similarly, three out of the five specific competencies also matched both times, again with the same or lower ratings. Diversityrelated skills such as "Cooperation with people from different cultures" and, in particular, "Ability to work in diversified teams" were considered less important for future employability, while "Social entrepreneurship" and "Building trust and good relations" were enhanced.

Thai experts (Table 4) were also consistent in their 2020 and 2024 estimates regarding the label 


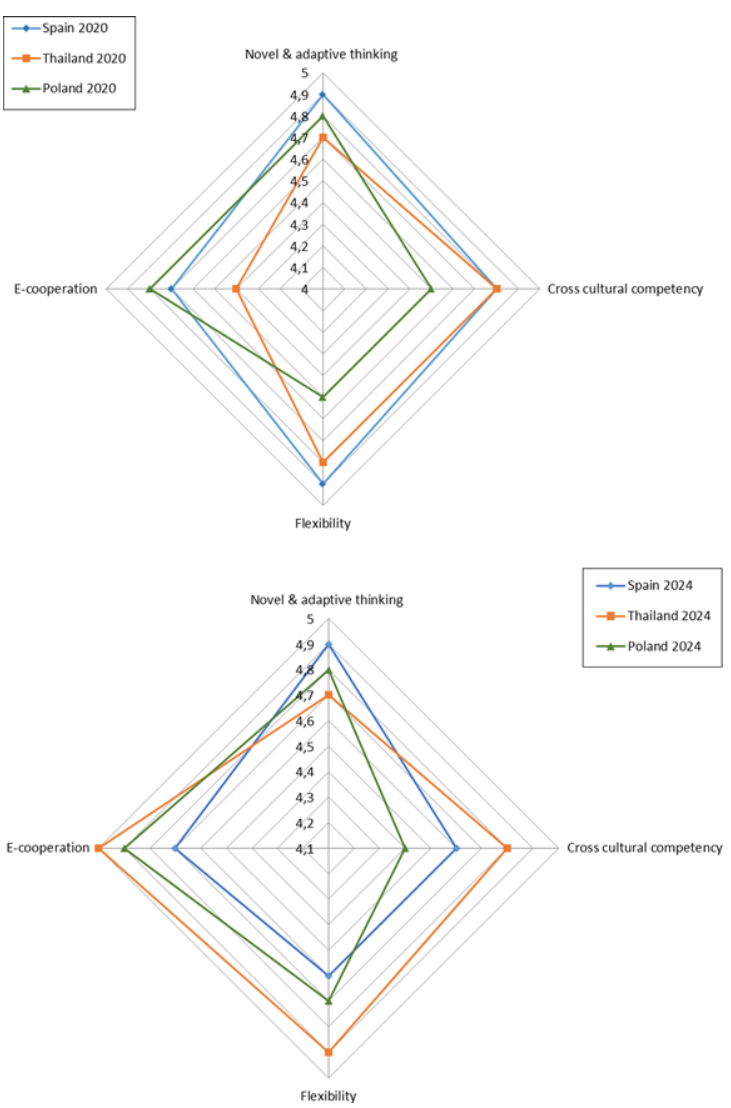

Fig. 2. Common competency expectations for 2024 across countries on 2019 and 2024.

and value of the generic competency ranking, only "Social intelligence" taking precedence over "New media literacy". Among the latter, it was remarkable that Thai experts considered "Design mind-set" a relevant future skill to develop, while Spanish and Polish experts did not give it much consideration. Moreover, three of the five specific competencies were likewise at the top of the ranking as future employability skills in both 2020 and 2024, with higher values in all cases. In this case, "E-cooperation" came first with a solid 5/5, along with "Conscious self-development", replacing "Virtual collaborative innovation" and "Work experience".

The experts in Poland (Table 5) likewise considered four out of five generic competencies to be among the top in 2020 and 2024, with more polarised values in the second round. "New media literacy" was replaced by "Transdisciplinarity" even though the latter had been valued with a lower mark. However, the ranking of the top specific competencies was more variable in this case, since only two skills were on both lists, namely "E-cooperation" and "Web-based collaborative innovation", the latter being relevant only in the Polish survey. It is also worth mentioning that Polish experts valued a diversity-related competency ("Ability to work on diversified teams") as a future skill as well as two ITrelated ones ("Web-based collaborative innovation" and "High technology entrepreneurship") to the detriment of social and self- management skills. External factors that may affect the labour market were thus considered by these experts.

\subsection{Estimates for 2020 vs. actual 2019 perceptions}

The third analysis compared the employability skills estimated by experts for 2020 with their actual responses in 2019. Starting with Poland (Table 4), expectations for 2020 were very similar to the values given for 2019, the most accurate forecast being that of the skillsets for required employability, although it is worth mentioning that the values were lower in all cases. The only differences were the appearance of "Social intelligence", "Project management" and "Flexibility" instead of "Building trust" and the more technical "Virtual collaboration" and "Collaborative innovation using web tools". Conversely, Thai estimates were the least accurate of the three panels (Table 4), predicting successfully only four of the ten top competencies, and giving more value to specific social skills and less to IT management skills than expected.

Finally, the Spanish experts (Table 3) expressed that their expectations were met regarding three generic competencies and three specific ones, although all of them with lower current values than in the estimates. "Sense-making" and "Virtual collaboration" were interchanged with "New media literacy" and Transdisciplinarity, while "E-cooperation" and "Cooperation with people representing different cultures" left the top five for the specific skills "Building trust and good relations" and "Conscious selfdevelopment". All cooperation-related skills were reranked into lower positions.

All in all, the views regarding what contributes to employability differed rather notably between countries, as did the levels of insight into present and future market demands. Nevertheless, there was a trend towards a consensus, with a prevalence of "Novel \& adaptive thinking" as the one common key employability skill across all three countries and years, often complemented with "Flexibility", "Learning skills" 
and "Cross-cultural competency". These results may help policy-makers and HEI professionals to complement the teaching curricula and align it better with present and future labour market demands.

\section{Discussion}

As illustrated above in the results section, at least half of the valuable employability skills changed over time across all three countries. The latter may indicate an evolution, either of the labour market or of experts' perceptions. Moreover, the rankings differed somewhat between countries, although a preference for self-management and social skills appeared to exist over technical or diversity-related skills. Digital communication skills seem to have been more valued than face-to-face ones, simply due to the growing relevance of digital work environments.

Spain seems to have been the most constant country over time and Thailand the most changing one, in terms of important employability skills. Thai and Polish experts focused more on IT skills than Spanish experts, who were more concerned with the development of social skills. These differences are compatible with the findings of [20]. who report different levels of IT readiness in different countries, particularly Poland's low scores on this issue, and reflects that the labour market calls for different needs depending on the country, even if they are in the same economic context as that of the European Union.

The one generic skill that was constantly perceived as highly relevant in all countries over both rounds was "Novel and adaptive thinking", which stresses the importance of being resourceful and resilient. Conversely, "Formal education", and, to some extent, "Work experience" significantly lost their value as employability skills in all countries. This presents food for thought for HEIs, more set on providing hard knowledge and developing formalised behaviours than on promoting soft skills. In fact, a majority of EU-based employers have never cooperated with HE institutions [59]. It is, therefore, necessary to develop strategic cooperation schemes involving the government, regulatory institutions, and labour market agents-individuals, companies, and educational institutions. The latter must be supported by governmental policies to implement initiatives that identify and provide training in valuable employability skills.

A new didactic approach is also required. Learning activities should reflect real world problems and teach to use interdisciplinary problem-solving techniques.
Projects such as the "learning factories" [60] and international collaborations among HEIs might contribute to building realistic learning scenarios that teach students to deal with unpredictable and complex problems, as well as to map good practices. This also means that lecturers and teachers must be open to changing their work routines and acquiring new skills to become lifelong learners.

Tools such as "Competent" [61], a competencybased information system, could increase the efficiency of these cooperation schemes, where datasets of employability skills, qualifications and job openings at the national level would be available to all stakeholders (namely: prospective employees, companies, jobseekers, students, and educational institutions). The constant updating and analysis of said datasets would be helpful to adjust education providers' programmes and didactic approaches to labour market needs. In addition, this information system could monitor the professional careers of recent graduates and be used as feedback to improve the system. In any case, without top-down government recommendations and appropriate financial support, it will be difficult to implement these measures in a realistic manner.

\section{Conclusions, limitations and future lines of research}

The present study contributes to the debate of the future of employability and education in the revolution 4.0. A longitudinal analysis of the views of academics and professionals on the skills required by the labour market helped identifying key employability skills and competencies in Spain, Thailand and Poland in 2016, 2020 and 2024.

In addition, the study aimed at outlining the prospective trends of these skill demands over the study period. In this regard, the views of the experts from all countries appeared to be altogether consistent regarding the most relevant competencies for future employability, if not with respect to the perceived values of such competencies in each country. A divergent and thought-provoking behaviour was found in the case of Poland. Only IT-related skills were consistently perceived as more relevant in the 2024 market than in the 2020 market, enhancing their importance for future employment. Nevertheless, the countries seemed to converge towards a common ranking, which could be interpreted as a reaction to a globalising labour market. The following theoretical 
implications thus arose as possible lines of research: if prospective employability needs are, according to the experts, constant over time, is the market changing as fast as everyone believes? Or, are HEIs not responding to market needs which would explain why these estimates remain the same?

The study's research results could also be used to propose practical recommendations to HEIs and human resource managers for bridging the employability gap in the current and future labour market. On the one hand, HEIs should respond to these critical skill shifts because future graduates' demands indicate that changes in the organisational culture and the pedagogical process must be made; indeed, soft skills are often related to personality and psychological features [2] and are not easily taught through traditional means. Introducing innovative methodologies that combine these skills and digital awareness, such as mobile gaming, could be a successful option [64]. The current Covid-19 pandemic has led HEIs' managers and faculty to be abruptly confronted with these concerns, shedding light on their key role to educators and students alike. HEIs should also consider complementing their staff with experts in the development of employability skills. They should also educate their own academics in the use of ICT and how to address this employability gap.

On the other hand, companies should facilitate the human resource practices that enhance the employability of their workforce, thus creating their own competitive talent base. Recruitment, promotion and training programmes in companies should take these skills into consideration, going beyond the traditional importance of formal education (given today) and work experience, and focusing on competency management policies instead. This way, teleworking or performance-based job descriptions, rather than being a challenge, would represent a competitive advantage in the digital economy.

\subsection{Limitations and future research avenues}

To finish, this study presented certain limitations that create a number of avenues for future research. First, the list of chosen competencies comprised only 10 generic ones (as identified in the literature) and twice as many specific ones. Even though the experts were asked to add missing competencies to the list, none were put forward. Second, the experts were asked to use a Likert scale from 1-5, therefore giving them a limited value range, and thus small differences. The findings of this study could, however, serve as the basis for a quantitative survey, leading to more comprehensive research, using other statistical tools such as Common Factor Analysis. Future studies should also consider adding the views of graduate students to the expert panel, given that other researchers [32] have pointed to such participation as a strategic contribution to the research topic.

\section{Acknowledgements}

This study was funded by the National Science Center (Poland) in the framework of the project "Competence Potential of Selected Employee Groups in Terms of Diversity Management in Innovative Enterprises", project No. 2013/09/b/hs4/01307.

\section{Author contributions}

CONCEPTION: Anna Rakowska

METHODOLOGY: Anna Rakowska and Susana de Juana

DATA COLLECTION: Anna Rakowska and Susana de Juana

INTERPRETATION OR ANALYSIS OF DATA: Anna Rakowska and Susana de Juana PREPARATION OF THE MANUSCRIPT: Anna Rakowska and Susana de Juana REVISION FOR IMPORTANT INTELLECTUAL CONTENT: Anna Rakowska and Susana de Juana SUPERVISION: Anna Rakowska

\section{References}

[1] Cambridge Business English Dictionary, https://dictionary.cambridge.org/pl/dictionary/english/labour-market.

[2] Ehlers UD, Kellermann SA. Future Skills: The future of learning and higher education. Ulf-Daniel Ehlers. Karlsruhe. Germany, (2019). pp. 2-69.

[3] Volini E, Schwartz J, Roy I, Hauptmann M, Van Durme Y, Denny B, Bersin J. (2019). Learning in the flow of life 2019 Global Human Capital Trends. Available at: https://www2. deloitte.com/us/en/insights/focus/human-capital-trends/ 2019/reskilling-upskilling-the-future-of-learning-anddevelopment.html.

[4] Valenduc G. New forms of work and employment in the digital economy. In The deconstruction of employment as a political question (2019), (pp. 63-80). Palgrave Macmillan, Cham.

[5] Xu M, David JM, Kim SH. The fourth industrial revolution: opportunities and challenges. International Journal of Financial Research. 2018;9(2):90-5. 
[6] Lee M, Yun J, Pyka A, Won D, Kodama F, SchiumaG, Yan MR. How to respond to the Fourth Industrial Revolution, or the Second Information Technology Revolution? Dynamic new combinations between technology, market, and society through open innovation. Journal of Open Innovation: Technology, Market, and Complexity. 2018;4(3):21.

[7] Hillage J, Pollard E. (1998). Employability: Developing a Framework for Policy Analysis. London: DfEE

[8] Fajaryati N, Budiyono, Akhyar M, Wiranto. The Employability Skills Needed To Face the Demands of Work in the Future: Systematic Literature Reviews. Open Engineering. 2020;10(1):595-603. https://doi.org/10.1515/eng2020-0072

[9] Deloitte (2018). Skills gap and future of work in manufacturing study. Available at: https://www2.deloitte.com/ content/dam/insights/us/articles/4736_2018-Deloitteskills-gap-FoW-manufacturing/DI_2018-Deloitte-skillsgap-FoW-manufacturing-study

[10] Baert S, Verhaest D. (2018). Unemployment or Over education: Which is a worse signal to employers? De Economist. http://doi.org/10.1007/s10645-018-9330-2

[11] Clarke M. Rethinking graduate employability: the role of capital, individual attributes and context. Studies in Higher Education. 2017;43(11):1923-37.

[12] Börner K, Scrivner O, Gallant M, Ma S, Liu X, Chewning K, Evans JA. Skill discrepancies between research, education, and jobs reveal the critical need to supply soft skills for the data economy. Proceedings of the National Academy of Sciences. 2018;115(50):12630-7.

[13] Shahroom AA, Hussin N. Industrial revolution 4.0 and education. International Journal of Academic Research in Business and Social Sciences. 2018;8(9):314-9.

[14] Hromcová J, Agnese P. Globalization, welfare, and the attitudes toward higher education. Economic Modelling. 2019;81:503-17.

[15] Di Fabio A. A review of empirical studies on employability and measures of employability. In Psychology of career adaptability, employability and resilience (2017), (pp. 107123). Springer, Cham.

[16] Suleman F. The employability skills of higher education graduates: insights into conceptual frameworks and methodological options. Higher Education. 2018;76(2):263-78.

[17] ARENE (2007). The Bologna Process and Finnish Universities of Applied Sciences. Participation of Finnish Universities of Applied Sciences in the European Higher Education Area. The Final Report of the Project. Helsinki: EditaPrima Oy

[18] Moore T, Morton J. The myth of job readiness? Written communication, employability, and the 'skills gap' in higher education. Studies in Higher Education. 2017;42(3): 591-609.

[19] Başol O, Yalçin EC. How does the digital economy and society index (DESI) affect labor market indicators in EU countries? Human Systems Management. (Preprint) 2020;40:1-10

[20] Naudé W, Surdej A, Cameron M. Ready for Industry 4.0? The Case of Central and Eastern Europe. In Industry 4.0 and Engineering for a Sustainable Future. Springer Cham. (2019), pp. 153-75.

[21] Directorate-General for Employment, social affairs and inclusion, European Commission. (2016). New Skills for
Europa. Available at https://ec.europa.eu/social/main.jsp? catId $=1223$.

[22] Puriwat W, Tripopsakul S. Preparing for Industry 4.0 - Will youths have enough essential skills?: An Evidence from Thailand. International Journal of Instruction. 2020;13:89104. http://doi.org/10.29333/iji.2020.1337a

[23] Khidhir S. (2019). Singapore is getting 4.0 ready. Retrieved on 2020 December 4. Available at: https://theaseanpost. com/article/singapore-getting-40-ready.

[24] Institute for the Future (2011). Future Work Skills 2020. Retrieved on 2020 December 4. Available at: https://www. iftf.org/futureworkskills/

[25] UK Commission for Employment and Skills (2014). The future of work: jobs and skills in 2030. Retrieved on 2020 December 8. Available at: https://www.gov.uk/govern ment/publications/jobs-and-skills-in-2030.

[26] Hoftijzer M, Gortazar L. (2018). Skills and Europe's Labor Market: How Technological Change and Other Drivers of Skill Demand and Supply are Shaping Europe's Labor Market. World Bank, Washington, DC. World Bank. Retrieved on 2020 November 8. Available at: https://openknowledge. worldbank.org

[27] Mason AD, Kehayova V, Yang J. (2018). Trade, Technology, Skills and Jobs Exploring the Road Ahead for Developing East Asia". Background Paper for Sustaining the Revival of Middle-Income East Asia, forthcoming. World Bank, Washington, DC.

[28] Kongtong T, Phusavat K, Pastuszak Z, HidayantoAN, Majava J. Human capital development: A construct for underprivileged students. Human Systems Management. 2020;39(3):357-66. DOI 10.3233/HSM-190796

[29] Suleman F, Laranjeiro AM. The employability skills of graduates and employers' options in Portugal. Education+ Training, 2018;1097-1111.

[30] Trilling B, Fadel C. (2009). 21st century skills: Learning for life in our times. San Francisco, CA, US: Jossey-Bass.

[31] McKinsey (2018). Skill shift: Automation and the future of the workforce, 2018. Available at: https://www.mckinsey. com/ /media/mckinsey/industries/public\%20and\%20soci al\%20sector/our\%20insights/skill\%20shift\%20automation $\% 20$ and $\% 20$ the $\% 20$ future $\% 20$ of $\% 20$ the $\% 20$ workforce/ mgi-skill-shift-automation-and-future-of-the-workforcemay-2018

[32] Succi C, Canovi M. Soft skills to enhance graduate employability: comparing students and employers' perceptions. Studies in Higher Education. 2020;45(9): 1834-47.

[33] Claxton G, Costa AL, Kallick B. Hard thinking about soft skills. Educational Leadership. 2016;73(6):60-4.

[34] Plecher H. Employment by economic sector in Thailand 2020. Nov 4, 2020. Retrieved on 2020 December 8. Available at: https://www.statista.com/statistics/332222/ unemployment-rate-in-thailand/

[35] Neumann J. Why Spain Can't Shake One of World's Highest Unemployment Rates. Feb. 27, 2020. Retrieved on 2020 December 8. Available at https://www.bloomberg. com/news/articles/2020-02-27/why-spain-can-t-shakeone-of-world-s-highest-unemployment-rates

[36] EUROSTAT (2020). News release: Euroindicators. Euro area unemployment at $7.4 \%$. 30 January 2020 . Retrieved on 2020 December 8. Available at https://ec.europa.eu/ 
eurostat/documents/2995521/10159296/3-30012020-APEN.pdf/b9a98100-6917-c3ea-a544-ce288ac09675,

[37] Plecher H. (2020) Poland: Unemployment rate from 1999 to 2020. Oct 28, 2020. Retrieved on 2020 December 8. Available at https://www.statista.com/statistics/263705/ unemployment-rate-in-poland/.

[38] OECD (2020). Selected indicators for Spain. Retrieved on 2020 December 8. Available at: https://data.oecd.org/ spain.htm.

[39] STATISTA (2020). Poland - Employment by economic sector. Retrieved on 2020 December 8. Available at: https:// www.statista.com/statistics/376395/employment-byeconomic-sector-in-poland/.

[40] QS (2016). Higher Education Systems Strength Rankings. Retrieved on 2020 December 8. Available at https://www. topuniversities.com/system-strength-rankings/2016.

[41] OECD (2020). Education, countries. Retrieved on 2020 December 6. Available at http://www.oecd.org/education/.

[42] World education news and reviews (2018). Education in Thailand. February 6, 2018. Retrieved on 2020 December 6. Available at https://wenr.wes.org/2018/02/education-inthailand-2.

[43] Tappanai B, Staff R. Half of Thai graduates work in jobs unrelated to their degrees: survey. October 22, 2019. Retrieved on 2020 December 6. Available at https://www. khaosodenglish.com/news/2019/10/22/half-of-thaigraduates-work-in-jobs-unrelated-to-their-degrees-survey/.

[44] OECD (2018). Getting Skills Right: Spain. April 26, 2018. Retrieved on 2020 December 6. Available at https://www. oecd.org/spain/getting-skills-right-spain-9789264282346en.htm

[45] OECD (2019). Skills Strategy for Poland. December 11, 2019. Retrieved on 2020 December 6. Available at https:// www.oecd.org/skills/oecd-skills-strategy-poland-b377f bcc-en.htm.

[46] World Bank (2018). Skills and Europe's Labor Market How Technological Change and Other Drivers of Skill Demand and Supply are shaping Europe's Labor market. Retrieved on 2020 December 6. Available at: http://pubdocs.world bank.org/en/115971529687983521/EU-GU-Skills-andLabor-Markets-final-5-29-2018.pdf.

[47] Johnson RB, Onwuegbuzie AJ. Mixed methods research: A research paradigm whose time has come. Educational Researcher. 2004;33(7):14-26.

[48] Hart L, Smith S, Swars S, Smith M. An examination of research methods in mathematics education (1995-2005). Journal of Mixed Methods Research. 2009;3(1):26-41.

[49] Richardson S, Bennett D, MacKinnon P, Mahat M, Poronnik P, Coates H, Schmidt L. (2015). Embedding employability in the Curriculum-Strategies to improve outcomes for university graduates; Available at: https://conference.pixelonline.net/FOE/files/foe/ed0005/FP/1592-SOE971-FPFOE5

[50] Sulea C. Future skills at work: a perspective on critical skills. Psihologia Resurselor Umane. 2018;16(2):56-8.

[51] Tiili JUHO, Suhonen SAMI. (2019). Physics lab as learning environment for important engineering skills. Proceedings of the 10th PTEE. Available at: http://sefiphysics.be/ mirror_PTEE2019/proceedings

[52] Field R. Teaching Resilience and Self-Management Skills: Fostering Student Psychological Wellbeing for Future
Employability. In Education for Employability (2019), (Volume 2) (pp. 237-246). Brill Sense.

[53] Loveland TR. Teaching personal skills in technology and engineering education: Is it our job? It is every teacher's responsibility to prepare youth to be professional and ethi$\mathrm{cal}$ in their future dealings in classrooms or the workplace. Technology and Engineering Teacher. 2017;76(7):15.

[54] Van Laar E, Van Deursen AJ, Van Dijk JA, De Haan J. The relation between 21st-century skills and digital skills: A systematic literature review. Computers in Human Behavior. 2017;72:577-88.

[55] Sapovadia VK. (2019). Role of HR in Employability Skills of 21 st Century. Retrieved on 2020 December 6. Available at: https://sapovadiacom.wordpress.com/2019/09/02/roleof-hr-in-employability-skills-of-21st-century/

[56] Williams P. Assessing collaborative learning: big data, analytics and university futures. Assessment \& Evaluation in Higher Education. 2017;42(6):978-89.

[57] Siddiq F, Scherer R. Is there a gender gap? A meta-analysis of the gender differences in students' ICT literacy. Educational Research Review. 2019;27:205-17.

[58] Chin JL, Desormeaux L, Sawyer K. Making way for paradigms of diversity leadership. Consulting Psychology Journal: Practice and Research. 2016;68(1):49-71.

[59] Ornellas A, Falkner K, Stålbrandt E. Enhancing graduates' employability skills through authentic learning approaches. Higher Education, Skills and Work-Based Learning. 2019;9(1).

[60] Tisch M, Metternich J. Potentials and limits of learning factories in research, innovation transfer, education, and training. Procedia Manufacturing. 2017;9:89-96.

[61] European Center for the Development of Vocational Training (Competent. Retrieved on 2020 December 1. Available at https://www.cedefop.europa.eu/en/tools/matchingskills/all-instruments/competent-name-database.

[62] Tomlinson M. Conceptions of the value of higher education in a measured market. Higher Education. 2018;75(4): 711-27.

[63] Beam EA, Hyman J, Theoharides C. The Relative Returns to Education, Experience, and Attractiveness for Young Workers. Economic Development and Cultural Change. 2020;68(2):391-428.

[64] Mivehchi L, Rajabion L. A framework for evaluating the impact of mobile games, technological innovation and collaborative learning on students' motivation. Human Systems Management. 2020;39(1):27-36.

\section{Annex 1}

SKILLS ASSESSMENT. Importance of skills today (2015) and tomorrow (2020)

Please indicate below, how important, in your opinion, are the below listed skills. First column refers to the importance of given skill today (as of 2015), and the other column to how important that same skill will be in five years' time. If you think that a new skill/ competence should be added, please write it down. 
684 A. Rakowska and S. de Juana-Espinosa / Ready for the future? Employability skills and competencies in the twenty-first century

Importance: $1=$ not important at all; $2=$ slightly important; $3=$ moderately important $; 4=$ very important; $5=$ extremely important

\begin{tabular}{|c|c|c|c|}
\hline & Skill/competence & $\begin{array}{l}\text { Importance } \\
2015\end{array}$ & $\begin{array}{l}\text { Importance } \\
2020\end{array}$ \\
\hline 1. & Sense-making. Ability to determine the deeper meaning of significance of what is being expressed. & 12345 & 12345 \\
\hline 2 & $\begin{array}{l}\text { Social intelligence. Ability to connect to others in a deep and direct way, to sense and stimulate } \\
\text { reactions and desired interactions. }\end{array}$ & 12345 & 12345 \\
\hline 3 & $\begin{array}{l}\text { Novel \& adaptive thinking. Proficiency at thinking and coming up with solutions and responses } \\
\text { beyond that which is routine rule based. }\end{array}$ & 12345 & 12345 \\
\hline 4 & $\begin{array}{l}\text { Cross cultural competency. Ability to operate in different cultural settings. Linguistic skills, } \\
\text { adaptability to changing circumstances, ability to sense and respond to new contexts. }\end{array}$ & 12345 & 12345 \\
\hline 5 & $\begin{array}{l}\text { Computational thinking. Ability to translate vast amount of data into abstract concepts, models, } \\
\text { understanding of data-based reasoning. }\end{array}$ & 12345 & 12345 \\
\hline 6 & $\begin{array}{l}\text { New media literacy. Ability to critically asses and develop content that uses new media forms, and } \\
\text { to leverage these media for persuasive communication. }\end{array}$ & 12345 & 12345 \\
\hline 7 & Transdisciplinarity. Literacy in and ability to understand concepts across multiple disciplines. & 12345 & 12345 \\
\hline 8 & Design mindset. Ability to represent and develop tasks and work processes for desired outcomes. & 12345 & 12345 \\
\hline 9 & $\begin{array}{l}\text { Cognitive load management. Ability to discriminate and filter information, and to understand } \\
\text { how to maximize cognitive functioning by using a variety of tools and techniques. }\end{array}$ & 12345 & 12345 \\
\hline 10 & $\begin{array}{l}\text { Virtual collaboration. Ability to work productively, drive engagement, and demonstrate presence } \\
\text { as a member of a virtual team. } \\
\text { Specific skills }\end{array}$ & 12345 & 12345 \\
\hline 11 & Conscious self-development & 12345 & 12345 \\
\hline 12 & Ability to self-mobilize to long time working & 12345 & 12345 \\
\hline 13 & Personal stress management & 12345 & 12345 \\
\hline 14 & Learning skills & 12345 & 12345 \\
\hline 15 & Flexibility & 12345 & 12345 \\
\hline 16 & Uncertainty tolerance & 12345 & 12345 \\
\hline 17 & Face to face communication & 12345 & 12345 \\
\hline 18 & Building trust and good relations & 12345 & 12345 \\
\hline 19 & E- cooperation & 12345 & 12345 \\
\hline 20 & Cooperation with people representing different cultures & 12345 & 12345 \\
\hline 21 & Cooperation with people representing different age & 12345 & 12345 \\
\hline 22 & Cooperation with people representing different sex & 12345 & 12345 \\
\hline 23 & Cooperation with people representing different religion & 12345 & 12345 \\
\hline 24 & Project management & 12345 & 12345 \\
\hline 25 & Ability to work in diversified teams & 12345 & 12345 \\
\hline 26 & Social entrepreneurship & 12345 & 12345 \\
\hline 27 & High technology entrepreneurship & 12345 & 12345 \\
\hline 28 & Collaborative innovation with usage of web tools & 12345 & 12345 \\
\hline 29 & Big data, cloud management proficiency & 12345 & 12345 \\
\hline 30 & Formal education / diploma, Msc, BA & 12345 & 12345 \\
\hline 31 & Work experience & 12345 & 12345 \\
\hline
\end{tabular}

